\title{
Evaluation of the behavior of levels of HMGB1 and IL6 as predictors of infection, acute kidney injury and mortality in cirrhotic patients with variceal bleeding
}

\author{
Eduardo Garcia VILELA, Camilla dos Santos PINHEIRO, Saulo Fernandes SATURNINO, \\ Célio Geraldo de Oliveira GOMES, Vanuza Chagas do NASCIMENTO and Marcos Vinicius Melo de ANDRADE
}

\begin{abstract}
Background - Gastroesophageal varices and associated bleeding are a major cause of morbidity and mortality in cirrhotic patients. Objective - To evaluate the potential role of the biomarkers HMGB1 (High Mobility Group Box 1) and IL-6 (Interleukin-6) as predictors of infection, acute kidney injury and mortality in these patients. Methods - It is a prospective, observational study that included 32 cirrhotic patients with variceal bleeding. Results - The subjects'mean age was $52 \pm 5$ years and $20(62.5 \%)$ were male. The average MELD was $17.53 \pm 5$ and the average MELD-Na was $20.63 \pm 6.06$. Thirty patients $(93.3 \%)$ patients were Child-Pugh class B or C. Infection was present in 9 subjects (28.1\%), acute kidney injury was present in $6(18.1 \%)$ and $4(12.5 \%)$ patients died. The median serum levels of HMGB1 were $1487 \mathrm{pg} / \mathrm{mL}(0.1$ to 8593.1$)$ and the median serum level of IL-6 was $62.1 \mathrm{pg} / \mathrm{mL}$ (0.1 to 1102.4). The serum levels of HMGB1 and IL-6 were significantly higher in patients who developed infection, acute kidney injury and death $(P<0.05)$. The Spearman's correlations for HMGB1 and IL-6 were 0.794 and 0.374 for infection, 0.53 and 0.374 for acute kidney injury and 0.467 and 0.404 for death, respectively. Conclusion - Serum levels of HMGB1 and IL-6 were higher in patients with the three studied outcomes. HMGB1 serum levels showed a high correlation with infection and a moderate correlation with acute kidney injury and death, while IL-6 showed a moderate correlation with infection and death and a low correlation with acute kidney injury.
\end{abstract}

HEADINGS - Liver cirrhosis. Esophageal and gastric varices. Biomarkers.

\section{INTRODUCTION}

The development of variceal hemorrhage is a direct consequence of portal hypertension ${ }^{(1)}$. It occurs in 25 to $40 \%$ of patients with cirrhosis, and each episode of active variceal hemorrhage is associated with a $10 \%$ to $20 \%$ of mortality ${ }^{(2,3)}$. Complications related to bleeding and the treatment of bleeding contribute substantially to mortality from active hemorrhage ${ }^{(4)}$. The principal complications that cause death are aspiration pneumonia, sepsis and renal failure ${ }^{(5,6)}$.

At the epithelial level, specifically in the small intestine, patients with liver cirrhosis present changes in barrier function. Increased intestinal permeability has been found in cirrhotic patients compared with healthy controls ${ }^{(7,8)}$. This increased permeability appears to be a result of the loosening of tight junctions associated not only with increased resistance to portal venous flow but also as a result of systemic circulatory dysfunction ${ }^{(9,10)}$. This circumstance favors the translocation of gram-negative bacteria across the intestinal barrier and may lead to infection and others complications. Most often, the bacteria are killed, but bacterial byproducts known as PAMPs (pathogen-associated molecular patterns) such as lipopolysaccharide and DAMPs (damage-associated molecular patterns) are released. PAMPs and DAMPs are spontaneously recognized by PRRs (pattern recognition receptors) expressed in immune and other types of cells. PRR engagement may result in the release of pro-inflammatory cytokines/chemokines, leading to systemic inflammation ${ }^{(11)}$.

Among various mediators of the acute or chronic inflammatory conditions that accentuate systemic vasodilation are stand HMGB1 (High Mobility Group Box 1) and IL-6 (Interleukin-6) ${ }^{(12,13)}$. HMGB1 is a type of DAMP, a pro-inflammatory nuclear protein actively secreted by the cells of the innate immune system and the hepatocytes, released as a result of apoptotic phenomena during the cell death process $^{(12)}$. When interacting with toll-like receptor 4 (TLR-4) - a type of PPR transmembrane - in one of its various signaling pathways, HMGB1 induces the activation of nuclear factor kappa $\mathrm{B}$, producing immunostimulatory responses through transcriptional pro-inflammatory genes, including tumor necrosis factor, Interleukin-1 and ultimately IL-6, the most important cytokyne in sepsis ${ }^{(13,14)}$.

The grade of inflammation parallels the severity of liver, circulatory and renal dysfunction and acute on chronic liver failure $(\mathrm{ACLF})^{(15,16)}$. Its deleterious effect on organ function may derive from reduced organ perfusion and/or the effects of cytokines and reactive oxygen species on cell function and apoptosis ${ }^{(17,18)}$. 
The aim of this study is to evaluate the association of the biomarkers HMGB1 and IL-6 with infection, acute kidney injury (AKI) and mortality in cirrhotic patients with variceal bleeding and determine the usefulness of these mediators as potential predictors of major outcomes.

\section{METHODS}

This was a prospective, observational study that included 32 patients diagnosed with liver cirrhosis with active bleeding resulting from rupture of gastroesophageal varices between June 2014 and March 2016. All the patients underwent endoscopic treatment via the ligation of esophageal varices or GOV1-type gastric varices associated with an intravenous bolus of octreotide $50 \mathrm{mcg}$ followed by $50 \mathrm{mcg} /$ hour for 5 days. Antimicrobial prophylaxis included norfloxacin $400 \mathrm{mg}$ every 12 hours for 7 days or ceftriaxone $1 \mathrm{~g}$ every 24 hours for same period, when appropriate. During the hospitalization period, demographic, clinical and laboratory data were collected to investigate the predictors of infection, AKI and mortality. Spontaneous bacterial peritonitis was defined as the presence of at least 250 polymorphonuclear leukocytes $/ \mathrm{mm}^{3}$ in ascitic fluid analyzes, in the absence of a source of peritoneal cavity infection. The criteria for the pneumonia diagnosis were symptoms of acute respiratory tract disease associated with at least one systemic finding - confusion, headache, sweating, chills and radiological infiltrate not previously present. Urinary tract infection was characterized by bacterial growth of at least $10^{5}$ colony forming units $/ \mathrm{mL}$ of urine $(100.000 \mathrm{cfu} / \mathrm{mL})$ associated with tract urinary symptoms. The diagnosis of AKI was defined by the presence of two creatinine values, with a difference of at least $0.3 \mathrm{mg} / \mathrm{dL}$ or the elevation of at least $50 \%$ of its baseline value. Baseline creatinine was defined as the most recent and stable value prior to hospital admission within a maximum interval of seven days. Four participants were excluded. Three of them decided not to sign the consent form and one patient was submitted to liver transplant in the acute phase of bleeding. The demographic variables included age and gender and the clinical variables were Child-Pugh classification, Model for End-Stage Liver Disease (MELD), MELD sodium, presence of ascites and length of hospitalization. The examined laboratory variables were hemoglobin level at admission and after 48 hours, platelet count on admission and after 48 hours, serum levels of HMGB1 and IL-6, serum creatinine, albumin, total bilirubin, prothrombin activity with INR, activated partial thromboplastin time, fibrinogen and sodium on admission. The need for blood components was also recorded.

Statistical analyses were performed using the Statistical Package for Social Sciences version 21.0 (SPSS, Inc., Chicago, IL). Numerical variables are presented as means and standard deviations or as minimums, maximums and medians if they did not present normal distribution (Kolmogorov-Smirnov test). Categorical variables were presented as percentages. The Mann-Whitney test was used to assess the associations between variables and Spearman's test was used to evaluate the correlation between serum levels of HMGB1 and IL-6 and infection, AKI and death.

\section{Ethics}

The study was approved by the Ethics Committee of the Federal University of Minas Gerais and was conducted in accordance with the 1975 Declaration of Helsinki (6th revision, 2008). All the patients signed a free informed consent form before beginning the study.

\section{RESULTS}

A total of 32 patients with mean age of 52 years \pm 10 were included; $20(62.5 \%)$ were male. Alcohol and hepatitis $\mathrm{C}$ were the main causes of cirrhosis (TABLE 1). Seventeen patients $(53.1 \%)$ were classified as Child-Pugh class C, $13(40.6 \%)$ were Child-Pugh class B, and $2(6.3 \%)$ were Child-Pugh class A. The mean MELD was $17.53 \pm 5$, and MELD-Na was 20.63 \pm 6.06 . The median hospitalization period was 8 days ${ }^{(5-17)}$. There was need for red blood cell transfusion in 11 patients $(34.4 \%)$ to maintain hemoglobin levels between 7 and $8 \mathrm{~g} / \mathrm{dL}$. Seven patients received platelet transfusions, and fresh frozen plasma and cryoprecipitate were used for one patient each. Infectious complications were present in $9(28.1 \%)$ patients (pneumonia in five, spontaneous bacterial peritonitis in three and urinary tract infection in one). AKI was observed in 6 $(18.1 \%)$ patients, and $4(12.5 \%)$ patients died. The median serum level of HMGB1 was $1487 \mathrm{pg} / \mathrm{mL}$ (0.1-8593.1); for IL-6, it was $62.1 \mathrm{pg} / \mathrm{mL}(0.1-1102.4)$.

TABLE 1. Etiology of cirrhosis $(n=32)$.

\begin{tabular}{lcc}
\hline Etiology & Frequency $(\mathbf{n})$ & Percentage \\
\hline Alcohol & 11 & 34.4 \\
Hepatitis C & 10 & 31.3 \\
Auto-immune hepatitis & 4 & 12.5 \\
Hepatitis B & 2 & 6.3 \\
Primary sclerosing colangitis & 2 & 6.3 \\
Primary biliar colangitis & 2 & 6.3 \\
Non-alcoholic stetohepatitis & 1 & 3.1 \\
\hline
\end{tabular}

After the univariate analysis for the evaluation of factors associated with mortality was performed, the variables MELD, MELD-Na, red blood cell transfusion, plasma transfusion, transfusion of cryoprecipitate, acute renal injury, sodium, serum HMGB1 and infection were entered into the initial model; however, none remained at the end of the multivariate analysis. For the outcomes infection and AKI, the variables HMBGB1, plasma transfusion, cryoprecipitate, albumin, sodium and length of hospitalization entered the initial model but did not remain with significance at the end of the model.

To evaluate the behavior of HMGB1 and IL-6 serum levels as outcome predictors, their medians were compared between patients who developed infection, AKI and mortality and those who did not. HMGB1 serum levels were higher in patients who developed infection $(P=0.000)$, AKI $(P=0.004)$ and death $(P=0.011)$. Regarding serum levels of interleukin-6, $P$-values were 0.002 for infection, 0.044 for AKI and 0.003 for mortality. Results are showed in TABLES 2, 3 and 4.

TABLE 2. Median serum HMGB1 and IL6 values in cirrhotic patients with and without infection.

\begin{tabular}{lccc}
\hline $\begin{array}{l}\text { Serum levels } \\
(\mathrm{pg} / \mathrm{mL})\end{array}$ & \multicolumn{2}{c}{ Infection } & \multirow{2}{*}{$\boldsymbol{P}$ value } \\
\cline { 1 - 3 } Median (Range) & Yes & No & \\
\hline HMGB1 & $4635(3535-8593)$ & $496(0.1-2536)$ & 0.000 \\
IL-6 & $132(80-1102)$ & $21.7(0.1-269)$ & 0.002 \\
\hline
\end{tabular}


TABLE 3. Median serum HMGB1 and IL6 values in cirrhotic patients with and without acute kidney injury.

\begin{tabular}{lccc}
\hline $\begin{array}{l}\text { Serum levels } \\
(\mathrm{pg} / \mathrm{mL})\end{array}$ & \multicolumn{2}{c}{ Acute kidney injury } & \multirow{2}{*}{$\boldsymbol{P}$ value } \\
\cline { 1 - 3 } Median (Range) & Yes & No & \\
\hline HMGB1 & $4222(2063-8593)$ & $548(0.1-5175)$ & 0.002 \\
IL-6 & $123(33.4-743)$ & $27(0.1-1102)$ & 0.044 \\
\hline
\end{tabular}

TABLE 4. Median serum HMGB1 and IL6 values in cirrhotic patients who had or did not evolve to death.

\begin{tabular}{lccc}
\hline $\begin{array}{l}\text { Serum levels } \\
(\mathrm{pg} / \mathrm{mL})\end{array}$ & \multicolumn{2}{c}{ Death } & \multirow{2}{*}{$\boldsymbol{P}$ value } \\
\cline { 1 - 3 } Median (range) & Yes & No & \\
\hline HMGB1 & $5446(1592-8593)$ & $596(0.1-4645)$ & 0.011 \\
IL-6 & $123(33.4-743)$ & $27(0.1-1102)$ & 0.003 \\
\hline
\end{tabular}

The correlation between HMGB1 and IL-6 values and the outcomes was determined using Spearman's coefficient (rho). The value of rho for HMGB1 for infection was 0.794; for AKI, the value was 0.530 ; and for mortality, the value was 0.467 . Regarding the rho coefficients for interleukin- 6 , the values were 0.567 for infection, 0.374 for AKI and 0.404 for mortality (TABLE 5). These results evidenced that the serum levels of HMGB1 showed a high correlation with infection and moderate correlations with AKI and mortality. Serum IL-6 levels showed a moderate correlation with infection and mortality and a low correlation with AKI.

TABLE 5. Spearman's coefficient (rho) between HMGB1 and Il-6 values and the outcomes.

\begin{tabular}{lccc}
\hline & Infection & Acute kidney injury & Death \\
\hline HMGB1 & 0.794 & 0.530 & 0.467 \\
IL-6 & 0.567 & 0.374 & 0.404 \\
\hline
\end{tabular}

Spearman's coefficient reference values (rho). $\mathrm{R}=1$ : perfect; $\mathrm{R}=0.80$ to $<1$ : very high; $\mathrm{R}=0.60$ to $<0.80$ : high; $\mathrm{R}=0.40$ to $<60$ : moderate; $\mathrm{R}=0.20$ to $<0.40$ : low; $\mathrm{R}=0$ to $<0.20$ very low; $\mathrm{R}=0$ : null.

\section{DISCUSSION}

Variceal hemorrhage is one of the most important consequences of portal hypertension. One-fourth of the patients with varices develop hemorrhage within 2 years (2). The prognosis of patients with variceal hemorrhage has improved over the last two decades as the understanding of the pathophysiology of portal hypertension has improved, but mortality remains at $10 \%$ to $20 \% 0^{(2,3)}$.

Interest in the use of inflammatory mediators as prognostic biomarkers is increasing. In Hepatology, interleukin-6 has been studied more frequently, but HMGB1 is not still recognized as a possible biomarker in these patients. Cai et al. ${ }^{(19)}$ evaluated 50 patients with hepatitis B virus (HBV)-related ACLF, 35 patients with liver cirrhosis, 35 patients with chronic hepatitis B and 35 healthy controls. HMGB1 concentrations continually declined in the survivors and increased in the nonsurvivors. Duan et al. ${ }^{(20)}$ evaluated the HMGB1 levels in the serum of 60 patients with HBV-related ACLF, 30 with chronic hepatitis B and 24 healthy individuals and investigated its potential relationship to the clinical features of these patients. Enhanced serum levels of HMGB1 were associated with the development of HBV-related ACLF in CHB patients. No study assessing HMGB1 as a prognostic marker for acute bleeding in cirrhotic patients was found. In the acute bleeding phase, circulatory dysfunction in cirrhotic patients worsens and is associated with a higher incidence of infection and other complications, such as AKI and hepatic encephalopathy, possibly via mechanisms that involve weakening of the gut barrier and bacterial translocation ${ }^{(16)}$.

In patients with liver disease, Kao et al. ${ }^{(21)}$ evaluated 158 naïve liver cirrhosis patients and 144 non-liver cirrhosis individuals and tested the correlations among the mediators IL-6, interleukin-27, tumor necrosis factor- $\alpha$ (TNF $\alpha)$ and vascular endothelial growth factor with STAT proteins at diverse clinical-pathologic stages in the cirrhotic patients. Over-expression of IL-6 reflects hepatic dysfunction and varices bleeding with mortality, as well as correlates p-STAT3 expression. A study published in 2012 evaluated the role of TNF- $\alpha$ and IL- 6 in cirrhotic patients who had hepatic and renal impairment with spontaneous bacterial peritonitis ${ }^{(22)}$. Approximately $40 \%(n=48)$ of cirrhotic patients with SBP developed renal and hepatic impairment and showed significantly higher plasma and ascitic fluid cytokine levels upon the diagnosis of infection ${ }^{(22)}$. In contrast, Elsing et al. ${ }^{(23)}$ did not find higher levels of IL-6 in patients with acute decompensation compared with non-decompensated patients. There was also no difference between the patients with and without bleeding.

In this study, it was established that serum levels of HMGB1 are higher in patients who developed infection, AKI and death compared with patients who did not have these outcomes and that the correlation was high for infection and moderate for AKI and death. Similar results were observed regarding serum IL-6 levels; however, the correlation was moderate for infection and death and low for AKI outcome.

Infectious complications and AKI are directly associated with cirrhotic circulatory dysfunction, a phenomenon whose main triggering factor is splanchnic arterial vasodilation secondary to portal hypertension ${ }^{(24)}$. However, these two outcomes, as well as other forms of organic dysfunction in cirrhosis, can occur even without the progression of circulatory dysfunction because they also result from the complex interaction between the innate immune system and bacterial components - also called PAMPs translocated from the intestinal lumen and DAMPs ${ }^{(15,25,26)}$. Once linked to PRRs, PAMPs and DAMPs activate several cascades of intracellular and extracellular signaling, producing proinflammatory responses that, when excessive or chronic, can cause tissue damage ${ }^{(27,28)}$. Thus, infection complications and AKI in cirrhosis should be interpreted as resulting not only from arterial vasodilation but also from exacerbated systemic inflammation ${ }^{(27)}$. Among various mediators of acute or chronic inflammatory states that accentuate systemic vasodilation and are associated with organ failure, HMGB1 and IL-6 are the most prominent ${ }^{(29)}$. HMGB1, a type of DAMP, is a proinflammatory nuclear protein that is actively secreted by cells of the innate immune system and released during apoptosis, including hepatocytes in the process of cell death ${ }^{(30)}$. By interacting with the toll-like receptor 4 - a type of transmembrane PRR - in one of its several signaling pathways, HMGB1 induces the activation of nuclear factor kappa B, producing immunostimulatory responses via the transcription of proinflammatory genes, including tumor necrosis factor, interleu- 
kin-1 and, also, IL-6 $6^{(31)}$. Likewise, HMGB1 can accumulate in the renal tissue and urine, stimulating the production of inflammatory cytokines, including IL-6, through interaction with toll-like receptors $4^{(32)}$. Elevated levels of toll-like receptors 4 are found in the renal tubular cells of cirrhotic patients with AKI, suggesting that these receptors may mediate renal injury in the context of infection or systemic inflammation ${ }^{(33)}$.

\section{CONCLUSION}

The intrinsic relationship between these inflammatory mediators and the endpoints studied strengthens the likelihood that they may also function as prognostic markers. The higher performance of HMGB1 may be related to its function as DAMP at the beginning of the inflammatory cascade independent of the stimulus of other mediators, as with IL-6.

\section{AKNOWLEDGEMENTS}

We thank Fundação de Amparo à Pesquisa do Estado de Minas Gerais (FAPEMIG) for the financial assistance to carry out this research and physicians Claudia Maria de Castro Mendes, Ludmila Resende Guedes, Henrique Carvalho Rocha, Roberto Gardone Guimarães and Fernando Antônio Castro Carvalho and medical students Natália Maria Câmara da Luz, Guilherme Massote Fontanini and Thayana Simplício de Faria who contributed to the conclusion of this article.

\section{Authors' contribution}

Vilela EG performed the data collection and the statistical analysis. Vilela EG, Saturnino SF and Andrade MVM wrote, edited and formatted the article. Gomes CGO and Pinheiro CS reviewed the article and Nascimento VC performed the exams.

Vilela EG, Pinheiro CS, Saturnino SF, Gomes CGO, Nascimento VC, Andrade MVM. Avaliação do comportamento dos níveis séricos de HMGB1 e IL-6 como preditores de infecção, injúria renal aguda e mortalidade em pacientes cirróticos com varizes sangrantes. Arq Gastroenterol. 2018;55(4):338-42.

RESUMO - Contexto - Varizes esofagogástricas são a maior causa de morbimortalidade em pacientes cirróticos. Objetivo - Avaliar o papel de biomarcadores, High Mobility Group Box 1 (HMGB 1) e interleucina-6 (IL-6) como preditores de infecção, injúria renal aguda e mortalidade nestes pacientes. Métodos - Estudo prospectivo, observacional que incluiu 32 pacientes com cirrose hepática na fase aguda do sangramento. Resultados - A média de

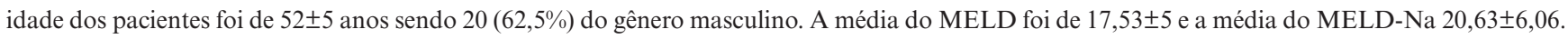
Trinta $(93,3 \%)$ pacientes foram classificados como Child B ou C. Complicação infecciosa esteve presente em $9(28,1 \%)$ pacientes, injúria renal aguda em $6(18,1 \%)$ e $4(12,5 \%)$ evoluíram para o óbito. A mediana do nível sérico de HMGB 1 foi de 1487 pg/mL $(0,1-8593,1)$ e da IL-6 foi de $62,1 \mathrm{pg} / \mathrm{mL}$ (0,1-1102,4). Os níveis séricos de HMGB 1 e IL-6 foram significativamente maiores nos pacientes que evoluíram com infecção, injúria renal aguda e óbito $(P<0,05)$. Os valores da correlação de Spearman para os níveis séricos de HMGB 1 e IL-6 foram de 0,794 e 0,374 para infecção, 0,53 e 0,374 para injuria renal aguda e 0,467 e 0,404 para óbito, respectivamente. Conclusão - Níveis séricos de HMGB 1 e IL-6 foram maiores nos três desfechos estudados. Níveis séricos de HMGB 1 apresentaram alta correlação para com o desfecho infecção e moderada correlação para com injúria renal aguda e óbito, enquanto os níveis séricos de IL-6 apresentaram moderada correlação para com infecção e óbito e baixa correlação para com injúria renal aguda.

DESCRITORES - Cirrose hepática. Varizes esofágicas e gástricas. Biomarcadores.

\section{REFERENCES}

1. Garcia-Tsao G, Bosch J. Management of varices and variceal hemorrhage in cirrhosis. N Engl J Med. 2010;362:823.

2. de Franchis R. Expanding consensus in portal hypertension Report of the Baveno VI Consensus Workshop: Stratifying risk and individualizing care for portal hypertension. Journal of Hepatology. 2015;63:1272-84.

3. Graham DY, Smith JL. The course of patients after variceal hemorrhage. Gastroenterology. 1981; 80:800-9.

4. D'Amico, G, Morabito, A, Pagliaro, L. Six week prognostic indicators in upper gastrointestinal hemorrhage in cirrhotics. Front Gastrointest Res. 1986;9:247-51

5. Koch DG, Arguedas MR, Fallon MB. Risk of aspiration pneumonia in suspected variceal hemorrhage: the value of prophylactic endotracheal intubation prior to endoscopy. Dig Dis Sci. 2007;52:2225-8.

6. Grace ND. Prevention of initial variceal hemorrhage. Gastroenterol Clin North Am. 1992;21:149-61.

7. Liboredo JC, Vilela EG, Ferrari M de L, Lima AS, Correia MI. Nutrition status and intestinal permeability in patients eligible for liver transplantation. J Parent Enteral Nutr. 2015;39:163-70.

8. Cariello R, Federico A, Sapone A, Tuccillo C, Scialdone VR, Tiso A, et al. Intestinal permeability in patients with chronic liver diseases: its relationship with the aetiology and the entity of liver damage. Dig Liver Dis. 2010;42:200-4.

9. Xu W-H, Wu W-J, Li J-S. Influence of portal pressure change on intestinal permeability in patients with portal hypertension. Hepatobiliary Pancreat Dis Int. 2002;1:510-4.

10. Pascual S, Such J, Esteban A, Zapater P, Casellas JÁ, Aparicio JR, et al. Intestinal permeability is increased in patients with advances cirrosis. Hepatogastroenterology. 2003;50:1482-6.
11. Waidmann O, Brunner F, Herrmann E, Zeuzem S, Piiper A, Kronenberger B. Macrophage activation is a prognostic parameter for variceal bleeding and overall survival in patients with liver cirrhosis. J Hepatol. 2013;58:956-61.

12. Albillos A, Lario M, Alvarez-Mon M. Cirrhosis-associated immune dysfunction: Distinct features and clinical relevance. J Hepatol. 2014;61:1385-96.

13. Wiest R, Lawson M, Geuking M. Pathological bacterial translocation in liver cirrhosis. J Hepatol. 2014; 60:197-209.

14. Gandoura S, Weiss E, Ratou PE, Fassen M, Gustot T, Lemoine F, et al. Gene and exon-expression profiling reveals an extensive LPS-induced response in immune cells in patients with cirrhosis. J Hepatol. 2013;58:936-48.

15. Arroyo V, Moreau R, Jalan R, Ginès P; EASL-CLIF Consortium CANONIC Study. Acute-on-chronic liver failure: A new syndrome that will re-classify cirrhosis. J Hepatol. 2015;62(1 Suppl):S131-43.

16. Moreau R, Jalan R, Gines P, Pavesi M, Angeli P, Cordoba J, et al. Acute-on chronic liver failure is a distinct syndrome that develops in patients with acute decompensation of cirrhosis. Gastroenterology. 2013;144:1426-37.

17. Navasa M, Follo A, Filella X, Jiménez W, Francitorra A, Planas R, et al. Tumor necrosis factor and interleukin-6 in spontaneous bacterial peritonitis in cirrhosis: relationship with the development of renal impairment and mortality. Hepatology. 1998;27:1227-32

18. Romero-Gomez R, Montagnese S, Jalan R. Hepatic encephalopathy in patients with acute decompensation and acute-on-chronic liver failure. J Hepatol. 2015;62:437-47.

19. Cai J, Han T, Nie C, Jia X, Liu Y, Zhu Z, et al. Biomarkers of oxidation stress, inflammation, necrosis and apoptosis are associated with hepatitis B-related acute-on-chronic liver failure. Clin Res Hepatol Gastroenterol. 2016;40:41-50. 
20. Duan XZ, Hu JH, Li C, Liu XZ, Hu JH, Tong JJ, et al. Relation between serum levels of high mobility group box 1 and hepatitis $\mathrm{B}$ virus-related acute-on-chronic liver failure. Zhonghua Gan Zang Bing Za Zhi. 2013;21:434-7.

21. Kao JT, Yu CJ, Feng CL, Tsai SM, Chen YL, Wu YY. IL-6 significantly correlates with p-STAT3 expression and presents high variceal bleeding with mortality in cirrhotic patients: A cross-sectional study. J Microbiol Immunol Infect. 2017;50:286-96.

22. Suliman MA, Khalil FM, Alkindi SS, Pathare AV, Almadhani AA, Soliman NA Tumor necrosis factor- $\alpha$ and interleukin- 6 in cirrhotic patients with spontaneous bacterial peritonitis. World J Gastrointest Pathophysiol. 2012;15:92-8.

23. Elsing C, Harenberg S, Stremmel W, Herrmann T. Serum levels of soluble Fas, nitric oxide and cytokines in acute decompensated cirrhotic patients. World $\mathrm{J}$ Gastroenterol. 2007;13:421-5.

24. Ruiz-del-Arbol L, Monescillo A, Arocena C, Valer P, Gines P, Moreira V, et al. Circulatory function and hepatorenal syndrome in cirrhosis. Hepatology. 2005;42:439-47.

25. Kawai T, Akira S. The role of pattern-recognition receptors in innate immunity: update on Toll-like receptors. Nat Immunol. 2010;11:373-84.

26. Kumar H, Kawai T, Akira S. Pathogen recognition by the innate immune system. Int Rev Immunol. 2011;30:16-34.
27. Bernardi M, Moreau R, Angeli P, Schnabl B, Arroyo V. Mechanisms of decompensation and organ failure in cirrhosis: From peripheral arterial vasodilation to systemic inflammation hypothesis. J Hepatol. 2015;63:1272-84.

28. Medzhitov R, Schneider DS, Soares MP. Disease tolerance as a defense strategy. Science. 2012;335:936-41.

29. Doi K, Rabb H. Impact of acute kidney injury on distant organ function: recent findings and potential therapeutic targets. Kidney Int. 2016;89:555-64.

30. Lotze MT, Tracey KJ. High-mobility group box 1 protein (HMGB1): nuclear weapon in the immune arsenal. Nat Rev Immunol. 2005;5:331-42.

31. Park JS, Svetkauskaite D, He Q, Kim JY, Strassheim D, Ishizaka A, et al. Involvement of toll-like receptors 2 and 4 in cellular activation by high mobility group box 1 protein. J Biol Chem. 2004;279:7370-7.

32. Zheng S, Pan Y, Wang C, Liu Y, Shi M, Ding G. HMGB1 Turns Renal Tubular Epithelial Cells into Inflammatory Promoters by Interacting with TLR4 During Sepsis. J Interferon Cytokine Res. 2016;36:9-19.

33. Shah N, Mohamed FE, Jover-Cobos M, Macnaughtan J, Davies N, Moreau R, et al. Increased renal expression and urinary excretion of TLR4 in acute kidney injury associated with cirrhosis. Liver Int. 2013;33:398-409. 